東海地方における自転車通勤者の健康・体力レベルと通勤時の走行実態

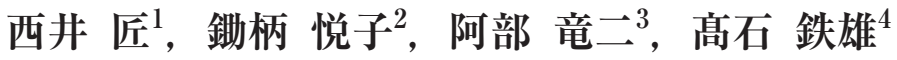

\title{
Fitness level and physical capacity of commuter cyclists and the actual condition while cycling to work in Tokai region
}

\author{
Takumi Nishii $^{1}$, Etsuko Sukigara ${ }^{2}$, Ryuji Abe $^{3}$ and Tetsuo Takaishi ${ }^{4}$ \\ 1 三重大学社会連携研究センター, テ514-8507 三重県津市栗真町屋町1577 (Community-University Research Cooperation \\ Center, Mie University, 1577 Kurimamachiya-cho Tsu City, Mie 514-8507, Japan) \\ 2 愛知文教女子短期大学, 干492-8521 愛知県稲沢市稲葉2-9-17 (Aichi Bunkyo Women's College, 2-9-17 Inaba Inazawa \\ City, Aichi 492-8521, Japan) \\ ${ }^{3}$ 株式会社シマノ，＝590-8577 大阪府堺市堺区老松町3-77 (Shimano Inc., 3-77 Oimatsu-cho Sakai-ku Sakai City, Osaka \\ 590-8577, Japan) \\ 4 名古屋市立大学大学院システム自然科学研究科, †467-8501 愛知県名古屋市瑞穂区瑞穂町山の畑 1 (Graduate School \\ of Natural Sciences, Nagoya City University, 1 Yamanohata Mizuho-cho Mizuho-ku Nagoya City, Aichi 467-8501, \\ Japan)
}

Received: September 7, 2011 / Accepted: December 12, 2011

\begin{abstract}
The purpose of this study was to reveal physiological conditions of commuter cyclist from the standpoint of multiple approaches. Ten male employees ( $37 \pm 9 \mathrm{yr})$ who usually commute by bicycle participated in this study. Global Positioning System (GPS) was used to analyze their commuting route three-dimensionally. And heart rate was recorded simultaneously to determine their exercise intensity. Blood test, oral glucose tolerance test (OGTT), and maximal aerobic test was conducted in our laboratory. Semantic differential method (SD) questionnaire was conducted to clarify their feelings during and after their commute. The results of blood test and OGTT showed that all of determined values were good and no one exceeded the standard value. GPS log showed that subjects covered $13.3 \pm 7.2 \mathrm{~km}$ and $40 \pm 20$ minute with integrating $201 \pm 114$ meter altitude gain per commute. Heart rate data showed $129 \pm 12 \mathrm{bpm}$ per commute. However, subjects demonstrated higher peak heart rate during their commute ranged between 157 and $181 \mathrm{bpm}$, we determined details by frequency distribution method. The data revealed that commuter cycling was consisted by aerobic exercise with intermittent vigorous intensity exercise. Despite of such a hard exercise cycling to work, the result of SD questionnaire indicated that subjects felt briskness with less tiredness when they commute. Commuter cycling with a higher than moderate exercise intensity, could have good physical and mental effects for employees.
\end{abstract}

Jpn J Phys Fitness Sports Med, 61(2): 251-258 (2012)

Keywords : health condition, ecology, daily exercise, GPS

\section{I. 緒言}

地球環境への配慮, 健康に関する意識の高まりなどに より，近年，自転車利用が見直されている，中でも自転 車通勤は健康増進に役立つことが一般論として認知され ており, 疾病に伴う早世の回避につながる1), 冠状動脈 性心疾患のリスクを低下させる2,3)，体重増加の防止に 有効である ${ }^{4-7)}$, 徒歩通勤よりも心肺機能改善に効果が 期待できる ${ }^{8)}$ ，体力を向上させる ${ }^{910)}$ などの報告がある.

一方でわが国における自転車通勤者の健康状態や走行
中の運動強度に関する報告は，筆者の知るところ鈴木 $ら^{111}$ が通勤時の主観的運動強度を調查した報告のみであ る。しかもわが国の自転車に関わる道路事情は欧米と比 して自転車専用道が少ない, 交差点が多いなど, 一定速 度を保った状態で安全に自転車走行をすることが困難で あるという特徵を持つ.このため, 海外の研究報告にあ る自転車走行の内容や運動強度はわが国の自転車通勤の 実態とは異なる可能性がある。

その自転車通勤に関する先行研究であるが，通勤時の 走行実態についてまで詳しく検討されている報告は筆者 
らの知るところ見当たらない。すすわち，従来の研究で は走行速度や通勤距離，あるいは通勤に要した時間など の平均值が示されているだけであり, 自転車通勤者が具 体的にどのような運動強度や走行速度で通勤し, その結 果どのような健康効果を得ているかは未解明のままであ る。したがって，既に自転車通勤を実践している人につ いて通勤時の運動強度や通勤時間，頻度などの実態と血 液検査值, 体力測定などの評価值との関連性をより明確 にし，自転車通勤が実際にどの程度健康増進に役立つの かを科学的に示すことは, 自転車通勤を健康づくりに有 効な一つの運動 (エクササイズ) として社会に提言する上 で重要と考える。そこで本研究の目的は, 自転車通勤者 に対して血液検査，体力測定，アンケート等を行い，自 転車通勤者の健康状態や体力を明らかにすること，自転 車通勤中の運動強度変化や走行実態について詳細に検討 することである。

\section{II. 方法}

A. 被検者 東海地方在住の日常的に自転車通勤を行っ ている成人男性 10 名 $($ 年齢 $37 \pm 9$ 歳, 身長 $171.5 \pm 3.0 \mathrm{~cm}$, 体重 $62.6 \pm 4.3 \mathrm{~kg}$, 自転車通勤歷 $5.6 \pm 4.0$ 年, 通勤頻度 $3.6 \pm$ 1.2 回/週. 平均值土標準偏差) を被検者とした. 被検者 はクロスバイク，ロードレーサー，マウンテンバイクと いったスポーツ自転車を通勤に利用していたが，定期的 に自転車競技に参加し，通勤を競技練習の一環としてい る者は含まれていなかった。自転車通勤以外の運動を日 常的に行なっている者は 3 名(水泳 1 名, 週末のサイク リング 2 名)いたが, それ以外の 7 名は自転車通勤以外 に日常的な運動を行なっていなかった，実験に先立ち， 被検者は研究の意義や危険性などの説明を受け，十分に 理解した上で自発的な意志で参加した。本研究は名古屋 市立大学大学院システム自然科学研究科倫理委員会の承 認を受けて実施された。

\section{B. 測定項目}

1. 通勤経路, 通勤時心拍数等の測定 高石ら ${ }^{12)}$ の方法 に従い，携帯型のGPS(Garmin製，Geko201）を用いて通 勤中の三次元位置情報 (緯度, 経度, 高度)を 5 秒間隔で 記録した，携帯型GPSに記録されたデー夕は後に地形図 ソフトウェア ${ }^{13)} に$ にダウンロードし, 通勤経路を三次元的 に分析した(Fig 1)。被検者には連続する10日間の測定 期間中に同じ経路を往復するよう指示し, 往路・復路の いずれに打いても位置情報の欠損がない 2 試行以上の完 全な通勤デー夕を得た．得られたデータから 1 通勤ごと の移動距離，移動速度，積算上昇高度（通勤経路上にあ る上り勾配部分の高度差を累積した值たただし，GPSの 測定精度および運動強度への影響を考慮し, 高度差 $1.5 \mathrm{~m}$ 未満の上り勾配は除外)を分析し，往路・復路それぞ
れの平均值を算出して個人の通勤データとした。また GPSでの三次元位置情報の取得と同時に，自転車での利 用に機能特化した心拍数計(Polar製，S710i)を用い，通 勤時の心拍数, 走行速度, クランク回転数を 5 秒ごとに 記録した。通勤時の運動強度は各被検者の任意であった が，通常の通勤と同じ運動強度になるよう指示した。な お， 5 秒間の移動速度が $4 \mathrm{~km} / \mathrm{h}$ 未満のデー夕は停車と して取り扱った。これは本研究の被検者が使用していた 自転車の夕イヤ周長とギア比の関係から， $4 \mathrm{~km} / \mathrm{h}$ 未満 はクランク回転数が $9 \sim 16 \mathrm{rpm}$ 以下に相当し, 通常の自 転車走行をしている状態とは考えられないためである。 このような状況は抢そらく, 停車直前あるいは信号の変 わるタイミングを見計らって脚の動きを止めている際の 慣性走行にあたると考えられる。測定時期は2009年 3 月 19日から 8 月15日までであった。内訳は $3 \sim 4$ 月に調査 した被検者が 3 名， $5 \sim 6$ 月が 2 名， 7 〜月が 5 名で あった。調査期間中において, 雨天時に自転車通勤した 者はいなかった。な扮, 走行速度や運動強度は交差点等 に打ける発進や停止, 道路勾配の変化などの影響を強く 受けるため, 一通勤あたりの平均值だけで自転車通勤の 実態を論ずるだけでは不十分である。そこで走行速度と 心拍数については, 通勤時の経時的変化とそれらの度数 分布について自転車通勤の実態を詳細に検討した。
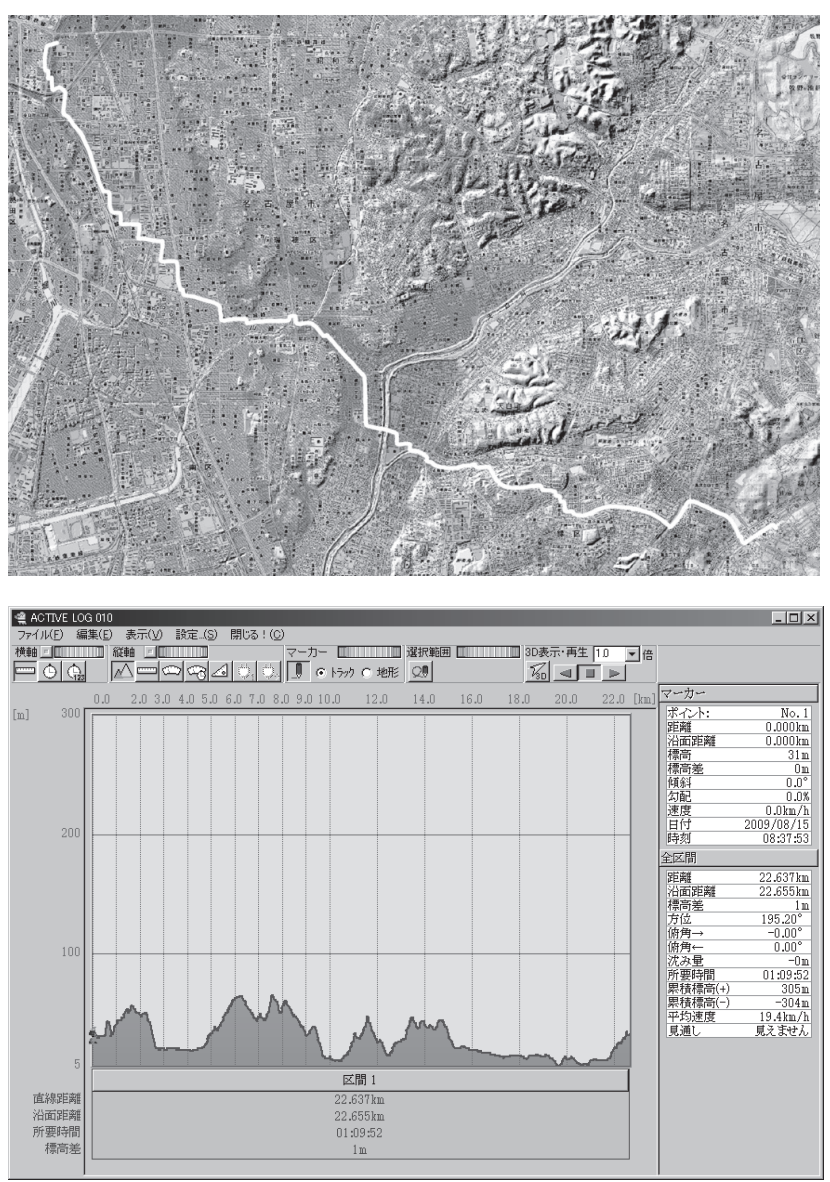

Fig 1. A representation of a typical commuting route and its course profile. 
2. 生理学的検査 被検者の健康状態を明らかにする ために, 空腹時血液検査, 経ログルコース負荷テスト (OGTT) を実施し，持久性能力の指標として最大酸素摂 取量ならびに最大心拍数を測定した. 空腹時血液検査に あたっては前日深夜 0 時より飲食を禁止し，実験当日の 午前 9 時に採血した。検査項目は, 総コレステロール,

HDLコレステロール (HDL-C), LDLコレステロール (LDL-C), 中性脂肪, 血糖, 糖化へモグロビン (HbAlc) であったＯGTTは上述の採血終了後にブドウ糖溶液 (味の素製薬製，トレーラン G液75g, 225ml，300kcal）を 摂取させ，血糖值変化を摂取 2 時間後まで30分ごとに測 定した。測定には携帯型血糖值測定器 (Arkray製, GT1641)を用いた。

最大酸素摂取量と最大心拍数は, 自転車エルゴメー ター(コンビ製，エアロバイク $232 \mathrm{C}$ )にて漸増負荷法に より測定した。負荷は 3 分ごとに $30 W$ 漸増した。本テス 卜時の有酸素性最大出力は, Kuipers et al. ${ }^{14)}$ の方法に従 い算出した。呼気ガスはポータブルガスモニター（アル コシステム製， AR-1)にて30秒ごとの值を測定・記録し た. 心拍数の測定には前述の心拍計(POLAR製，S710i) を用いた。本テストの際に得た安静時心拍数と最大心 拍数から予備心拍数 (HRR) を算出し, 自転車通勤時の \%HRRを算出した。

3. 心理学的調査 通勤時の感性評価のため, Semantic differential method(SD法)によるアンケート ${ }^{15)}$ を実施し た. 質問項目は(1)通勤によって疲労感を感じるか, (2)通 勤によって爽快感を感じるか, (3)通勤を身体トレーニン グの一環として取り組んでいるか, (4)通勤で汗をかきた いと思っているか, (5)通勤時に心肺機能を追い达もうと 思っているか, の 5 項目であった。評価尺度は11まった く感じない, (2)あまり感じない, (3)どちらでもない, (4) やや感じる, (5)かり感じる, の5 件法であった.

\section{III. 結 果}

A. 通勤時の走行実態 GPS等によって得られたデータ を分析した結果，通勤距離および通勤時間は，それぞれ $13.3 \pm 7.2 \mathrm{~km} ， 40 \pm 20$ 分で，1 通勤あたりの積算上昇高 度は201 $\pm 114 \mathrm{~m}$, 移動速度は20.1 $\pm 4.9 \mathrm{~km} / \mathrm{h}$, 走行中の クランク回転数は78 $78 \mathrm{rpm}$ であった。.心拍数のデータ を分析した結果, 通勤時の平均心拍数は $129 \pm 12 \mathrm{bpm}$ あり,これは $56 \pm 8 \% \mathrm{HRR}$ に相当した。一方, 各被検者 における通勤時の最高心拍数は157〜 181bpmで平均心拍

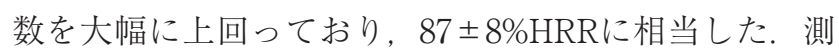
定時期が $3 \sim 4$ 月であった 3 名, 5 〜 月であった 2 名, 7 ～月 であった 5 名の最大心拍数と平均心拍数はぞ れぞれ168 $\pm 12 \mathrm{bpm}$ と $125 \pm 13 \mathrm{bpm}, 173 \pm 1 \mathrm{bpm}$ と $136 \pm$

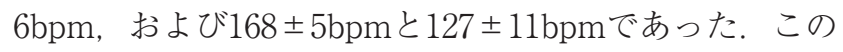
ように心拍数の平均值と最高值との差が大きかったこと
から，これらが信号や道路勾配などの影響を受けている 可能性があると考え, 走行速度と心拍数の経時的変化な らびにそれらの度数分布について詳細を検討した。典型 例として被検者一名の通勤(往路)における走行速度の結 果をFig 2 に，心拍数の結果をFig 3 に示す。この被検

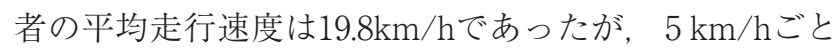
に区分した度数分布により 15〜 $29 \mathrm{~km} / \mathrm{h}$ 範囲にあたる 走行時間が全体の75\%を占めており，通勤時間の約 $10 \%$ が停車に該当することが明らかになった。同一通勤時の 平均心拍数については $139 \pm 17 \mathrm{bpm}$ であったが, 発進停 止を繰り返す中で間欠的に高強度運動が混在している ことが明らかとなった。度数分布によると最頻值は 140 〜149bpmの範囲であったが，150～159bpmの範囲が約 21\%，160～169bpmの範囲が約10\%を占めていた.
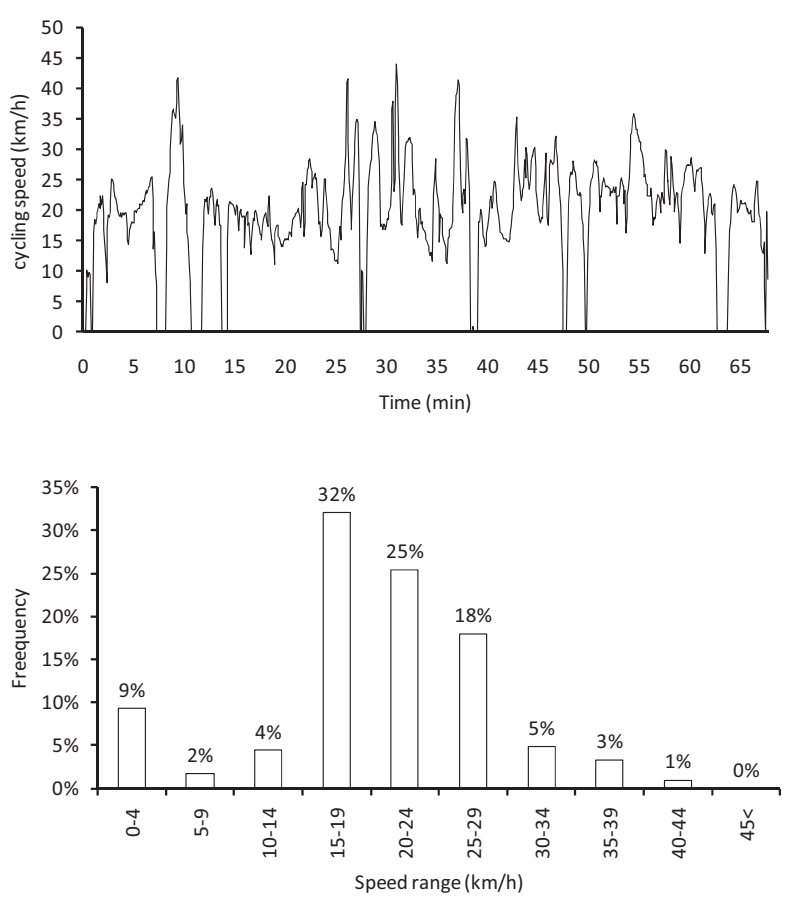

Fig 2. Detailed pattern of cycling speed and its frequency distribution for one commuter in one commute.

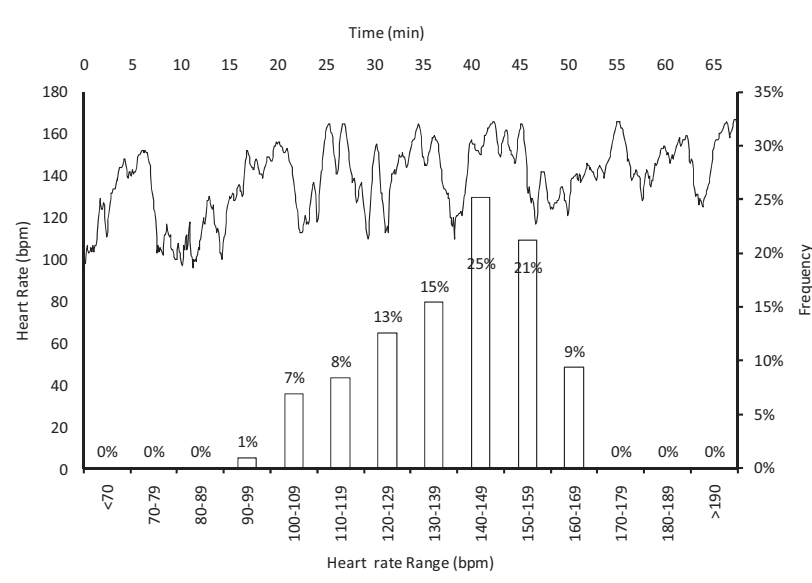

Fig 3. Detailed pattern of heart rate and its frequency distribution for the same commuter and commute as Fig 2. 
全被検者における通勤中の相対的運動強度 (\%HRR) を, 往路と復路の合計, 往路のみ, 復路のみに分けて 度数分布で示した (Fig 4). 往路と復路の合計における \%HRRの平均值は56\%HRRであったが，60～69\%HRRが 最頻值であった。 また, 就労後の疲労や日照条件の相違 による走行速度への影響を考慮し, 往路と復路を別個に 分析した. その結果, 最も走行時間の長い区分は往路に おいて60～69\%HRR，復路において50～59\%HRRであっ たが，同じ強度区分における往路と復路の間に統計的有 意差はなかった。 $50 \% H R R を$ 超える通勤時間の割合は往 路で76\%, 復路で65\%あり，70\%HRR超に限定しても往 路で $22 \%$, 復路で13\%観察されるなど，自転車通勤は高 強度運動を含む実態が明らかになった。走行速度につい ては往路が $22.8 \pm 3.8 \mathrm{~km} / \mathrm{h}$, 復路が $22.4 \pm 4.3 \mathrm{~km} / \mathrm{h}$ で統計 的有意差はなく, 就業後の疲労や日照条件の相違による 走行速度への影響は観察されなかった。出勤時刻ならび に通勤所要時間についての聞き取り調査では，どちらも 季節による大きな違いはないとのことであった。

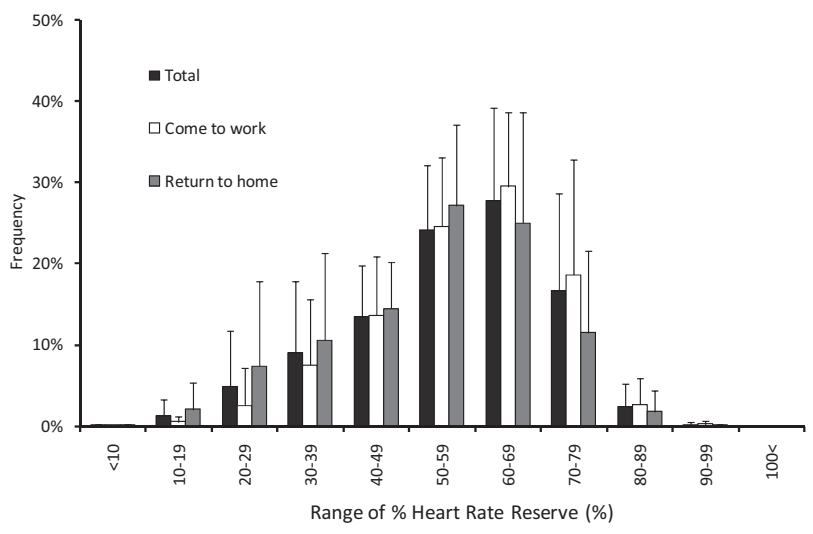

Fig 4. Exercise intensity and its frequency distribution of commuter cycling.

B. 生理学的検査 血液検査の結果をTable 1 に示す. 平均值は全て厚生労働省の特定健康診査基準值 ${ }^{16)}$ および 日本動脈硬化学会の総コレステロール, LDL-Cに関わ る基準值 ${ }^{17)}$ の範囲内であり，個々の測定值についても基 準值を外れる数值は観察されなかった。 OGTTの結果, 検査前空腹時の血糖值は $88 \pm 4 \mathrm{mg} / \mathrm{dl}$ であり, 各被検者 とも基準值 $(100 \mathrm{mg} / \mathrm{dl})$ 以下であった。糖負荷 30,60 , 90および120分後の值はそれぞれ $156 \pm 25,151 \pm 41,124$ \pm 20 ，および $110 \pm 17 \mathrm{mg} / \mathrm{dl}$ な゙あった。被検者の体重あ たりの最大酸素摂取量および最大心拍数は $55.9 \pm 8.7 \mathrm{ml} /$ $\mathrm{kg} / \mathrm{min} お よ ひ ゙ 187 \pm 11 \mathrm{bpm}$ であり，その際の仕事率は

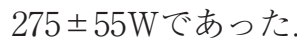

C. 心理学的検査 SDアンケートの結果をFig 5 に示す 被検者は通勤において疲労感よりむしろ爽快感を感じて いることが明らかとなった。また，自転車通勤をトレー
ニングの一部とは考えておらず，汗をかくことや息が上 がることを望んでいるわけではないことが明らかとなっ た。

Table 1. Summary of blood test.

\begin{tabular}{lcccc}
\hline & & average & \pm & $\mathrm{SD}$ \\
\hline Blood glucose & $(\mathrm{mg} / \mathrm{dL})$ & 88 & \pm & 4 \\
Total Cholesterol & $(\mathrm{mg} / \mathrm{dL})$ & 187 & \pm & 21 \\
HDL cholesterol & $(\mathrm{mg} / \mathrm{dL})$ & 66.8 & \pm & 16.4 \\
LDL cholesterol & $(\mathrm{mg} / \mathrm{dL})$ & 105.2 & \pm & 21.1 \\
LDL-C/HDL-C ratio & & 1.68 & \pm & 0.55 \\
Triglyceride & $(\mathrm{mg} / \mathrm{dL})$ & 64 & \pm & 18 \\
Hemoglobin A1c & $(\%)$ & 4.5 & \pm & 0.4 \\
\hline
\end{tabular}

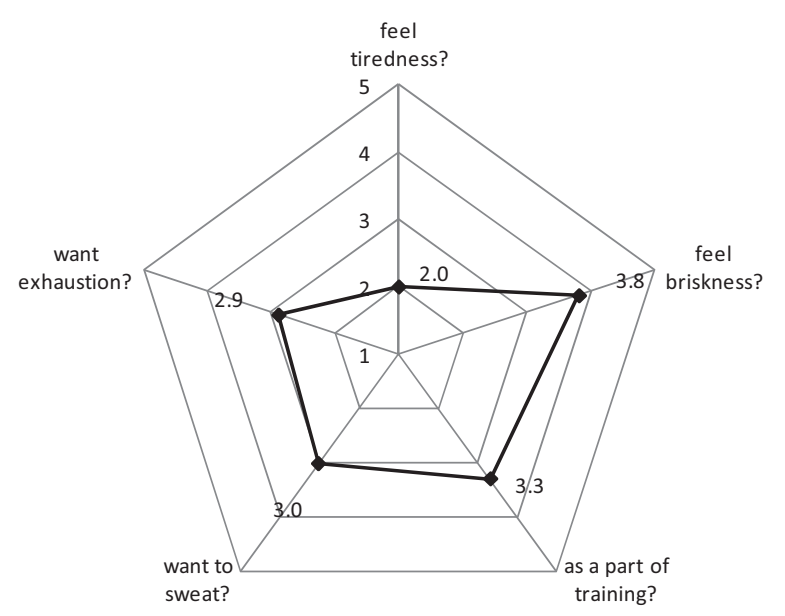

1: strongly NO; 2: NO; 3: neither; 4: YES; 5: strongly YES.

Fig 5. Analysis of feelings about commuter cycling.

\section{N. 考 察}

本研究では自転車通勤時の走行実態に着目し, 東海地 方在住の自転車通勤者における通勤時の運動強度, 走行 速度および心理指標などが健康状態ならびに体力レベル とどのような関わりがあるかを明らかにすることを目的 とした。 その結果, 本研究の自転車通勤者は血液検査の 結果が良好で有酸素性作業能力が高いことが示された。 またこのような特徵は, 間欠的に高強度域を含む有酸素 運動を日常的に高頻度で実践していることに起因する可 能性が示された。

A．通勤時の走行実態と運動強度 本研究の被検者にお ける通勤時の平均走行速度は約 $20 \mathrm{~km} / \mathrm{h}$ であり，平均心 拍数は約 $130 \mathrm{bpm}$ であった。この数值だけで見れば，本 研究の被検者はスポーツ自転車を利用しているにも関わ らず比較的ゆっくり楽に走っているようにも見える。と 
ころが各被検者の通勤時最高心拍数は157〜181bpmであ り，平均值とは大きくかけ離れていた。 そこで走行速度 と心拍数を経時的変化とその度数分布によって詳細に観 察した結果，自転車通勤は間欠的な高強度運動を含む持 久的運動であることが明らかとなった(Fig 2，3)。これ は通勤時間のうち約 $10 \%$ 停車に該当し，その度に再加 速が必要なこと，1 通勤あたり約 $200 \mathrm{~m} の$ 積算上昇高度 があったことなどが主たる要因と考えられる。これらは 従来の研究では明らかにされていなかった自転車通勤の 走行実態であり，GPSを用いて通勤時の走行速度变化な らびに通勤経路上の起伏を分析したことで初めて明らか になった事実と言える。

アメリカスポーツ医学会 $(\mathrm{ACSM})^{18)}$ は呼吸循環器機 能の向上のための運動として，50\%HRRを越える有酸素 運動を少なくとも週 3 回行うことを推奨している. 本研 究の被検者は一回の自転車通勤において職場と自宅を往 復しており,各々の間隔は 8 時間以上であった。つまり， 運動実施間隔がこのようにあく場合は，それぞれを独立 した運動と見なすほうが妥当である。したがって本研究 の被検者にみられた 3.6 回/週の自転車通勤は, 週に 7 回 強の有酸素運動実施と同義であったと考えられる。また 前述したように，本研究の被検者においては50\%HRR超 の出現頻度が往路で76\%，復路で65\%であった，本研究 の被検者が平均的な日本人のほぼ1.5倍に匹敵する高い 有酸素能力 ${ }^{19)}$ を獲得していたのは, 一回の運動強度が同 じであっても高頻度のほうが呼吸循環器機能が向上する こと ${ }^{20)}$, 中等度の定常運動に比べ運動強度に緩急をつけ たインターバルトレーニングのほうが呼吸循環器機能を より向上させること ${ }^{21)}$ の組み合わせによる相乗効果を反 映した可能性がある。ただし，本研究は限られた地域で 行われたものであり，交通量，交差点の数，通勤経路の 起伏など，わが国の典型的な道路事情を反映しているか は不明である。また，本研究の被検者がウォーキングな どに比べて強度の高い運動を日常的に行っていたことは 事実であるが，本研究はあくまで横断的研究であり自転 車通勤による体力維持・向上効果を明らかにするには介 入研究が必要である。な㧍本研究では測定実施期間が 3 月下旬から 8 月中旬であったため, 季節の相違が心拍数 に㧍よぼす影響についても検討した。しかしながら，測 定実施期間の相違による最大心拍数, 平均心拍数に一定 の傾向はなかった，同一被検者に打ける心拍数の季節変 動についてはデー夕を持たないが，聞き取り調査による と出勤時刻や通勤所要時間に大きな季節的変動はないと の回答であった。したがって，夏場は気温や湿度の影響 で心拍数が若干増加していた可能性がある，ただし，各 被検者における走行中の心拍数はいずれも安静時に比べ て十分に高いことから (Fig 3，4)，個々人の心拍数の季 節変動はその運動による効果に対して大きく影響してい
ないと推察される.

B. 自転車通勤者の血液検查各值 本研究に打ける被検 者の血清脂質各值は，いずれも厚生労働省の特定健康診 査基準 ${ }^{16)}$ あるいは動脈硬化学会が示す脂質代謝機能の診 断基準值以内であり ${ }^{17)}$ ，細山田ら ${ }^{22)} に よ る$ 年齢別平均と 比してより望ましいレベルにあった。これは運動経験の ない者に自転車通勤を 1 年間行わせた結果, LDL-Cの低 下ならびにHDL-Cの増加がともに有意であったとする de Gause et $\mathrm{al}^{23)}$ の報告や，中等度以上の有酸素運動の 継続は脂肪酸の需要量を増やし、リポタンパクリパーゼ の活性化を介してHDL-Cの増加抒よびLDL-Cの減少を もたらすとするBerg et $\mathrm{al}^{24)}$ の報告と一致する。ささらに 本研究では，自転車競技者が含まれていなかったにも関 わらず，スポーツ競技者の中でも HDL-Cが高く LDL-C が低いとされる長距離ランナーとほほ同様の血清脂質 值を示し ${ }^{25)}$ ，LDL-C/HDL-C比においては，血管内の プラーク体積が退縮傾向を示すとされる2.0を大幅に下 回った ${ }^{26)}$ 。これについては今回の調査で明らかになった ように, 本研究の被検者が平地のみならず 1 通勤あたり 積算 $200 \mathrm{~m}$ の高度上昇に相当する上り坂走行を日常的に 行っていたことが影響した可能性がある。またFig 2 か らFig 4 に見られるように，本研究の被検者たちは停車 から再加速し，そこから速やかに定常走行になるよう比 較的高強度の有酸素運動をインターバル形式で繰り返し ていた。これは中等度運動の継続よりもインターバル形 式による短時間の高強度運動が血清脂質の状態をより改 善したとするTjønna et al. ${ }^{27)}$ の報告と一致すると思われ, このような運動形態が血清脂質の状態にプラスに作用し たのかもしれない，本研究では走行中の酸素消費量は測 定していないが， $20 \mathrm{~km} / \mathrm{h}$ の自転車走行は $8 \mathrm{METs}$ に相当 するとの報告がある ${ }^{28)}$.これを今回の被検者の通勤時間, 通勤頻度，体重などを考慮して試算すると，エネルギー 消費量は約 $2500 \mathrm{kcal} /$ 週となる。本研究の被検者が良好 な脂質検查値を示した背景には，運動強度のみならず日 常的にこのようなエネルギー消費量を要する運動を継続 していることも要因の一つかもしれない，

本研究では自転車通勤者の糖代謝機能についても調査 した。そその結果，血糖值掞よびHbA1c值はいずれも基 準值内であり，平均年齢が37歳であったにも関わらずそ の平均值は大櫛ら ${ }^{29}$ による日本総合健診医学会の2002年 度調査結果の集計デー夕に基づく20歳台後半および20歳 台前半の平均值と同等であり，糖代謝機能が若く保たれ ていることが明らかになった. OGTTの結果については, 糖負荷 90 分後には 10 人中 8 人が，糖負荷 120 分後には全 員が $140 \mathrm{mg} / \mathrm{dL}$ 下回った。Gondoh et $\mathrm{al}^{30}{ }^{30}$ は，自転車 運動の強度が上がるにしたがって糖利用が促進されるこ とをPET（ポジトロン断層法）画像で明らかにしてい 
る。自転車通勤者における糖代謝機能を調査したものは Gondoh et al.の報告以外に例を見ないが, 通勤時におけ る中〜高強度の有酸素運動が大腿笳群での積極的な糖利 用を促し, その繰り返しが脚筋群のGLUT4を増やすこ

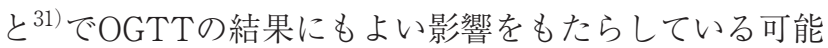
性がある。

血液検査の結果に対しては, 各自の食事内容あるいは 自転車通勤以外の運動などの影響も考えられる，前者に ついては今回調査していないが, 後者に関しては本研究 の被検者のうち 10 名中 7 名は自転車通勤以外に日常的な 運動を扢こなっていなかった。ただし残りの 3 名につい ては, 自転車通勤の実施頻度や運動量が大半を占めてい たものの，水泳あるいは週末のサイクリングが結果に影 響を拉よぼしていた可能性は否定できない。

C. 心理学的評価 SDアンケート調查の結果, 本研究 の被検者は通勤中に高強度域での運動が頻繁に出現する にもかかわらず，疲労感よりむしろ爽快感を得ていると いう大変興味深い回答を得た。 しかも被検者の半数を 7 〜8月に調査したが，軽く身体を動かしただけで汗ばむ 時期にあってもこのような回答が得られたことは特徵的 である。これはスピード感や風による空冷効果が疲労感 を軽減させているのかもしれないが，これについては今 後さらなる調査が必要であろう。しかしながらこのこと は先行研究と同様に, 自転車通勤が身体面の健康だけで なく精神面の健康にも貢献していることを示唆してい る ${ }^{3,9,32,33)}$. Ohta et $\mathrm{al}^{34}{ }^{34)}$ は, 徒歩あるいは自転車で通勤 している者はそうでない者と比較して精神衛生状態が有 意に優れていたと報告している．特に通勤所要時間が30 分以上の場合にその効果が顕著であったとしているが, 本研究の被検者も平均で40分の自転車通勤をしており, 同様の効果をもたらした可能性が高い.ささらに本研究で は自由回答も得たが，その中には「公共交通機関の混雑 や道路の啮滞が嫌い」「車は周囲の速度に合わせる必要 があるが, 自転車はマイペースで良く自由感が味わえる」 「その日の調子や気分に応じてマイペースで移動できる」 といった一般的な回答のほか，「会社に着いた後の爽快 感のため, 仕事がはかどる」,「朝の運動で頭が目覚め, 仕事がはかどる」と言った爽快感と作業効率に関する回 答や，「自転車に乗る社内の仲間同士での会話が弾む」 といった社会性への影響もあることが明らかとなった。 おそらくこれらが複数組み合わさり, 精神衛生面に貢献 していると推察される. 石井ら ${ }^{35}$ は男性において自転車 道の有無が自転車通勤の実施に影響していたことを報告 している，通勤先での自転車置き場，シャワーや更衣室 など，自転車利用環境の整備が労働者の体力レベルある いは精神衛生面を含めた健康レベルの向上につながる可 能性がある。
D. 本研究の限界 本研究はスポーツ自転車を利用し, 自転車通勤を好んで行なっている男性を対象とした。し たがって本研究の結果が女性や，わが国でもっとも普及 していると考えられる軽快車を利用して近距離の自転車 通勤をしている者にも適用できるかは不明である。また 本研究の被検者はすべて東海地方在住であった。つまり, 地域によって気候条件や道路・交通・地形といった環境 は異なるため，すべての地域で同様の結果が得られるか は不明である、さらに, 本研究はあくまで横断的研究で あり，健康状態抢よび体力レベルを向上させるにあたっ て必要な自転車通勤実施頻度と 1 回あたりの走行距離と の組み合わせ，あるいは実施期間などの詳細は明らかで はない。これらの点については今後の課題としたい.

\section{V.まとめ}

本研究は自転車通勤者の健康状態を多面的に明らかに することを目的とし，東海地方在住の日常的に自転車通 勤をしている成人男性10名を被検者として実態調査を行 なった。本研究では携带型GPSを用いて通勤経路を三次 元的に計測し, 通勤の実態と運動強度の関係性を詳細 に検討した。 また，血液検査，経口ブドウ糖負荷試験 (OGTT)，最大酸素摂取量の測定，アンケートによる感 性・感覚評価も実施した。その結果，以下の内容が明ら かとなった。

1. 自転車通勤は $50 \%$ HRR以上の運動が 1 通勤あたり 70\%以上含まれていることが明らかとなった。また， 信号停車後の再加速や 1 通勤あたり積算 $200 \mathrm{~m} の$ 高度 上昇を伴う登坂など，間欠的に運動強度変化を伴う 自転車走行が心肺諸機能に良い影響をもたらしてい る可能性が示された。

2. 本研究の被検者に扔ける有酸素性作業能力は平均的 な日本人のほほ1.5倍あった。血液検査とOGTTの值 はすべて基準值内であった，特にLDL-C/HDL-C比 は2.0を大幅に下回っていた.

3．上記のような高い運動強度で通勤しているにも関わ らず，被検者は疲労感よりむしろ爽快感を感じてい ることが明らかとなった。また，職場到着後の作業 効率や社内での社会性などにも良い影響を抢よぼし ている可能性が示された。

以上のまとめとして，東海地方におけるスポーツ自転 車を用いた自転車通勤は，身体的・精神的衛生面に良い 効果をもたらすと推察される.

\section{謝 辞}

本研究にご協力下さった被検者の方々，ならびに感性評 価についてご教授下さった中京大学情報理工学部・井口弘 和教授に深く感謝いたします。 


\section{文献}

1) Hamer M, Chida Y. Active commuting and cardiovascular risk: a meta-analytic review, Prev Med, 46: 9-13, 2008

2) Oja P, Manttari A, Heinonen A, Kukkonen-Harjula K, Laukkanen R, Pasanen M. Physiological effects of walking and cycling to work, Scand J Med Sci Sports, 151-157, 1991.

3) Hendriksen IJ, Zuiderveld B, Kemper HC, Bezemer PD. Effect of commuter cycling on physical performance of male and female employees, Med Sci Sports Exerc, 504-510, 2000.

4) $\mathrm{Hu}$ G, Pekkarinen $\mathrm{H}$, Hanninen $\mathrm{O}$, Tian H, Jin R. Comparison of dietary and non-dietary risk factors in overweight and normal-weight Chinese adults, Br J Nutr, 88: 91-97, 2002.

5) Lindström M. Means of transportation to work and overweight and obesity: a population-based study in southern Sweden, Prev Med, 46: 22-28, 2008.

6) Wen LM, Rissel C. Inverse associations between cycling to work, public transport, and overweight and obesity: Findings from a population based study in Australia, Prev Med, 46: 29-32. 2008.

7）高石鉄雄. 高石式アクティブサイクリング 自転車に乗 ろう!, 東京:土屋書店, 68-86, 2009.

8）中村博司, 高石鉄雄. 自転車で健康になる, 東京:日本経 済新聞出版社, 12-79, 2009.

9) de Geus B, Joncheere J, Meeusen R. Commuter cycling: effect on physical performance in untrained men and women in Flanders: minimum dose to improve indexes of fitness, Scand J Med Sci Sports, 179-187, 2009 .

10) Wagner A, Simon C, Ducimetiere P, Montaye M, Bongard V, Yarnell J. Leisure-time physical activity and regular walking or cycling to work are associated with adiposity and $5 \mathrm{y}$ weight gain in middle-aged men: the PRIME Study, Int J Obes Relat Metab Disord, 940-948, 2001.

11）鈴木邦雄, 林郁子, 荒木武. 自転車通勤の運動強度, 大阪 産業大学論集自然科学編, 97: 23-27, 1995.

12）高石鉄雄，山田美恵，田中勤，金若美幸，柳澤尚代. 位 置情報記録式GPS装置と心拍数記録装置を用いた高 齢者のウォーキング指導の提案, 日本公衆衛生雑誌, 56:172-183, 2009.

13）杉本智彦. カシミール3D GPSで山登り, 東京:実業之日 本社, 6-54, 2007.

14) Kuipers H, Verstappen FTJ, Keizer HA, Guerten P, Van Kraneburg G. Variability of aerobic performance in the laboratory and its physiological correlates, Int J Sports Med, 197-201, 1985.

15）大山正, 岩脇三良, 宮埜壽夫. 心理学研究法, 東京: サイ工 ンス社, 65-78, 2005.

16）厚生労働省。特定健康診査及び特定保健指導の実施 に関する基準, 2008. http://www.mhlw.go.jp/bunya/ shakaihosho/iryouseido01/dl/info03i-4.pdf

17）日本動脈硬化学会. 動脈硬化性疾患診療ガイドライン
(2007年版), 5-10, 2007.

18) American College of Sports Medicine Position Stand. The recommended quantity and quality of exercise for developing and maintaining cardiorespiratory and muscular fitness, and flexibility in healthy adults. Med Sci Sports Exerc, 30: 975-991. 1998.

19）鈴木政登. 日本人の健康関連体力指標最大酸素摂取量 基準域および望ましいレベル, 体力科学, 58: 5-6, 2009.

20) Wenger HA, Bell GJ. The interactions of intensity, frequency and duration of exercise training in altering cardiorespiratory fitness, Sports Med, 3: 346-356, 1986.

21) Helgerud J, Høydal K, Wang E, Karlsen T, Berg P, Bjerkaas M, Simonsen T, Helgesen C, Hjorth N, Bach $\mathrm{R}$, Hoff J. Aerobic high-intensity intervals improve VO2max more than moderate training, Med Sci Sports Exerc, 39: 665-671, 2007.

22）細山田真, 滝上裕, 鈴木友人, 木村真規, 柴崎敏昭. 日本 人における血清脂質の加齢性変化, 共立薬科大学雑誌, 2: 9-15, 2007.

23) de Geus, B, van Hoof E, Aerts I, Meeusen R. Cycling to work: influence on indexes of health in untrained men and women in Flanders. Coronary heart disease and Quality of life, Scan J Med Sci Sports, 18: 498-510, 2008.

24) Berg A, Frey I, Baumstark MW, Halle M, Keul J. Physical activity and lipoprotein lipid disorders, Sports Med, 17: 6-21, 1994.

25) Herbert PN, Bernier DN, Cullinane EM, Edelstein L, Kantor MA, Thompson PD. High-density lipoprotein metabolism in runners and sedentary men, JAMA, 252: 1034-1037, 1984.

26) Nicholls SJ, Tuzcu EM, Sipahi I, Grasso AW, Schoenhagen P, Hu T, Wolski K, Crowe T, Desai MY, Hazen SL, Kapadia SR, Nissen SE. Statins, high-density lipoprotein cholesterol, and regression of coronary atherosclerosis, JAMA, 297: 499-508, 2007.

27) Tjønna AE, Lee SJ, Rognmo Ø, Stølen TO, Bye A, Haram PM, Loennechen JP, Al-Share QY, Skogvoll E, Slørdahl SA, Kemi OJ, Najjar SM, Wisløff U. Aerobic interval training versus continuous moderate exercise as a treatment for the metabolic syndrome: a pilot study, Circulation, 118: 346-354, 2008.

28）厚生労働省. 健康作りのための運動指針2006, 2006. http://www.mhlw.go.jp/bunya/kenkou/undou01/pdf/ data.pdf

29）大櫛洋一, 柴田健, 小川哲平, 菅野剛史. 年齢別基準值の 意義と地域および年次比較, 総合検診, 95-105, 2004.

30) Gondoh Y, Tashiro M, Itoh M, Masud MM, Sensui H, Watanuki S, Ishii K, Takekura H, Nagatomi R, Fujimoto T. Evaluation of individual skeletal muscle activity by glucose uptake during pedaling exercise at different workloads using positron emission tomography, J Appl Physiol, 107: 599-604, 2009.

31) Phillips SM, Han XX, Green HJ, Bonen A. Increments in skeletal muscle GLUT-1 and GLUT-4 after endurance training in humans, Am J Physiol, 270 (3 Pt 1), 
E456-462, 1996.

32) Andersen LB, Schnohr P, Schroll M, Hein HO. Allcause mortality associated with physical activity during leisure time, work, sports, and cycling to work, Arch Intern Med, 160: 1621-1628, 2000.

33) de Geus B, S De Smet, J Nijs, R Meeusen. Determining the intensity and energy expenditure during commuter cycling. Br J Sports Med, 41: 8-12, 2007.
34) Ohta M, Mizoue T, Mishima N, Ikeda M. Effect of the physical activities in leisure time and commuting to work on mental health, J Occup Health, 49: 46-52, 2007.

35）石井香織, 柴田 愛, 岡 浩一朗, 井上茂, 下光輝一. 日本人成人における活動的な通勤手段に関連する環境 要因, 体力科学, 59: 215-24, 2010. 